\title{
Evaluasi Nilai Ekonomi Usaha Budi Daya Tanaman Jagung sebagai Tanaman Pakan dan Pangan di Kota Probolinggo
}

(Economic Evaluation of Maize Cultivation as Feed and Food in Probolinggo)

\author{
Sulistya TA, Anggraeny YN, Sukmasari PK \\ Loka Penelitian Sapi Potong, Jl. Pahlawan No. 2, Grati, Pasuruan, Jawa Timur \\ bapakelintang@gmail.com
}

\begin{abstract}
The aims of the evaluation was to determine the economic value of the cultivation of corn as feed plants than as food crops in the area of Probolinggo, East Java. The result is expected to be used as determining the type of maize cultivating at East Java. A total of 3 plots of corn seed plants were measured every 10 days up to 100 days of harvesting. The parameters taken were biomass production and corn production. Data is processed and presented in descriptive qualitative concerning total, total receipts of business, the value of benefit/cost $(\mathrm{B} / \mathrm{C})$ ratio, and the Break Event Point (BEP). The results show that the corn farming activities more profitable than feed farming activities. The profit rate of corn farming activities is Rp 11,777,553.00/ha, with the $\mathrm{B} / \mathrm{C}$ ratio is 1.9 , greater than feed farming activities that have level of profit is $\mathrm{Rp} 6,345,556.00$ and the $\mathrm{B} / \mathrm{C}$ ratio of 1.7 .
\end{abstract}

Key Words: Economic, Maize, Feed, Food

\begin{abstract}
ABSTRAK
Kegiatan evaluasi ini bertujuan untuk menghitung nilai ekonomi usaha budi daya jagung sebagai tanaman pakan dibandingkan dengan sebagai tanaman pangan di wilayah Kota Probolinggo, Jawa Timur. Hasil kegiatan ini diharapkan dapat dijadikan dasar dalam penentuan jenis usaha petani budi daya jagung di Jawa Timur. Sebanyak tiga petak tanaman jagung benih BISI 226 milik petani digunakan untuk pengukuran parameter produksi secara ubinan (ukuran $2,5 \times 2,5 \mathrm{~m}$ ) di lima titik lokasi setiap 10 hari hingga umur panen 100 hari. Parameter yang diamati adalah produksi biomassa tebon jagung dan produksi biji jagung pipilan kering. Dilakukan pula pencatatan seluruh pengeluaran usaha budi daya jagung sejak tanam hingga panen. Data diolah dan disajikan secara deskriptif kualitatif pada total pengeluaran usaha, total penerimaan usaha, nilai rasio benefit/cost (B/C) dan titik break event point (BEP) pada usaha budi daya jagung. Hasil kegiatan menunjukkan bahwa kegiatan usaha budi daya jagung sebagai tanaman pangan lebih menguntungkan dengan tingkat keuntungan Rp. 11.777.553/ha dengan nilai rasio B/C sebesar 1,9, lebih besar dari pada usaha budi daya tanaman jagung sebagai tanaman pakan yang mempunyai tingkat keuntungan Rp. 6.345.556 dengan nilai rasio B/C sebesar 1,7.
\end{abstract}

Kata Kunci: Nilai Ekonomi, Jagung, Pakan, Pangan

\section{PENDAHULUAN}

Dalam nomenklatur ekonomi tanaman pangan Indonesia, jagung merupakan komoditas penting kedua setelah padi/beras. Namun hanya sekitar $30 \%$ saja serapan pangan dari total produksi jagung nasional dan selebihnya adalah untuk industri pakan serta industri lainnya. Di Indonesia, pertumbuhan produksi jagung lebih disebabkan oleh perkembangan permintaan (demand driven) untuk pakan ternak, sedangkan pertumbuhan produksi tanaman pangan lain seperti padi disebabkan oleh supply driven karena didorong oleh inovasi teknologi benih unggul (Kasryno 2011). Untuk daerah dengan populasi ternak tinggi seperti di Jawa Timur sedikit banyak telah menstimulasi kenaikan permintaan tanaman jagung sebagai bahan pakan sumber serat. Tingginya permintaan pasar ini 
menjadikan masyarakat bergairah untuk membudi dayakan jagung sebagai salah satu usaha pertanian mereka. Hal ini menjadikan Jawa Timur tercatat sebagai lumbung jagung karena memberi kontribusi $40 \%$ terhadap produksi nasional dengan areal tanam sekitar 1,3 juta hektar (Soerjandono 2008).

Di sisi lain, tingginya populasi ternak sapi potong di Jawa Timur mencapai 4.267.325 ekor pada tahun 2015 (Disnak Jatim 2015), berimbas pada tingginya permintaan akan tanaman jagung utuh segar (tebon jagung) umur 70 hari sebagai pakan sapi potong. Permintaan pasar akan tebon jagung ini sangat dirasakan oleh petani jagung kota Probolinggo mengingat secara lokasi, mereka berdekatan dengan salah satu perusahaan penggemukan sapi potong terbesar di Indonesia yang mempunyai populasi sapi hingga ribuan ekor. Tingginya permintaan tebon jagung di Probolinggo mengakibatkan pergeseran fungsi budi daya tanaman jagung dari tanaman pangan penghasil biji jagung menjadi tanaman pakan sumber serat untuk sapi potong. Kondisi ini menjadikan tanaman jagung dapat dibudi dayakan oleh petani Probolinggo sebagai tanaman pangan penghasil biji jagung ataupun tanaman pakan sumber serat untuk sapi potong. Bila pergeseran usaha ini terus berlanjut dikhawatirkan akan meningkatkan impor biji jagung. Hal ini secara kualitas merugikan konsumen kita sendiri, mengingat protein jagung lokal Indonesia mempunyai kandungan protein yang relatif lebih tinggi dibanding jagung impor (Tangendjaja \& Wina 2007)

Dualisme fungsi budi daya jagung sebagai tanaman pangan dan pakan sapi potong ini menyebabkan petani jagung di Probolinggo belum bisa menentukan tujuan budi daya tanaman jagungnya di awal musim tanam. Penentuan usaha mereka baru bisa ditentukan pada saat tanaman jagung berumur 70 hari. Bila harga tebon jagung pada saat itu dirasa lebih menguntungkan maka usaha budi daya jagung akan dihentikan pada umur tersebut dan dijual dalam bentuk tebon jagung. Di sisi lain, bila dirasa harga jagung pipilan lebih menguntungkan maka tanaman jagungnya akan dibiarkan menua dan dipanen dalam bentuk jagung sebagai bahan pangan.

Kegiatan evaluasi ini bertujuan untuk membandingkan nilai ekonomi usaha budi daya tanaman jagung sebagai tanaman pakan sumber serat untuk sapi potong dibandingkan dengan usaha budi daya tanaman jagung sebagai tanaman pangan penghasil biji jagung. Hasil kegiatan evaluasi ini diharapkan mampu memberi gambaran nilai ekonomi kedua jenis usaha budi daya jagung tersebut dan dapat dijadikan acuan bagi petani dalam menentukan jenis usahanya lebih awal.

\section{MATERI DAN METODE}

Penelitian dilakukan di Kecamatan Kedopok, Kota Probolinggo pada bulan Oktober sampai Desember 2016. Sebanyak tiga petak lahan milik petani masing-masing $3.300 \mathrm{~m}^{2}$ ditanami jagung menggunakan pola tanam kebiasaan petani. Benih jagung yang ditanam adalah BISI 226 dengan terlebih dahulu dilakukan perendaman air bercampur fungisida selama 24 jam untuk mencegah serangan penyakit bulai pada tanaman muda. Benih jagung ditanam dengan jarak tanam $60 \mathrm{~cm}$ antar baris dan $20 \mathrm{~cm}$ antar tanaman dalam baris sehingga populasi 67.000 tanaman/ha. Jumlah benih yang ditanam dalam setiap lubang penanaman adalah 2 biji jagung. Pupuk dasar yang digunakan adalah $300 \mathrm{~kg}$ urea, $100 \mathrm{~kg}$ SP 36 dan $50 \mathrm{~kg} \mathrm{KCl} /$ ha diberikan pada awal tanam. Pupuk susulan berupa urea sebanyak $300 \mathrm{~kg}$ per Ha diberikan pada umur tanaman 15-20 HST (hari setelah tanam) dan 30-35 HST.

Pengamatan dimulai sejak penanaman biji jagung hingga pemanenan jagung umur 100 hari. Seluruh bentuk kegiatan budi daya yang mengakibatkan pengeluaran petani dinilai dalam bentuk rupiah sesuai dengan harga riil setempat pada saat kegiatan ini berlangsung 
untuk kemudian dicatat sebagai biaya pengeluaran. Hasil budi daya tanaman jagung berupa tebon jagung segar maupun biji jagung pipilan dinilai dalam bentuk rupiah sesuai dengan harga riil setempat pada saat kegiatan untuk kemudian dicatat sebagai pendapatan.

Parameter biaya pengeluaran usaha tani antara lain biaya sewa lahan, pengolahan lahan awal, pembelian benih, pembelian obat anti bulai, pembelian pupuk dasar dan susulan, serta seluruh tenaga kerja yang dikeluarkan berdasarkan upah wajar di lokasi. Sedangkan pengukuran nilai pendapatan berdasarkan parameter produksi dilakukan menggunakan metode ubinan $(2,5 \times 2,5 \mathrm{~m})$ secara acak pada lima titik berbeda pada tiap petaknya. Pengubinan dilakukan setiap 10 hari sejak umur 30 HST hingga 100 HST. Parameter produksi yang diamati adalah produksi total biomassa tebon jagung segar dan produksi jagung pipilan kering. Data biaya pengeluaran dan data produksi dari tiga petak lahan dirata-ratakan dan dibahas secara deskriptif kualitatif untuk mendapatkan perbandingan keekonomian usaha budi daya jagung sebagai tanaman pakan dibandingkan dengan budi daya jagung sebagai tanaman pangan.

\section{HASIL DAN PEMBAHASAN}

Penentuan lokasi penelitian usaha budi daya tanaman jagung sebagai tanaman pangan dan tanaman pakan ini mengambil tempat di Kelompok Tani Progo Jaya, Kecamatan Kedopok Kota Probolinggo sesuai dengan arahan Dinas Peternakan Kota Probolinggo. Lokasi tersebut dijadikan tempat evaluasi karena tingkat produksi jagung yang cukup tinggi. Rata-rata petani budi daya jagung menggunakan lahan milik pemerintah Kota Probolinggo yang disewakan tahunan kepada petani. Dengan sistem sewa tahunan tersebut maka pemilihan jagung sebagai jenis tanaman budi daya oleh petani dirasa paling ekonomis mengingat umur jagung hibrida sekarang hanya sekitar 100-110 hari, sehingga dalam setahun masa sewa dapat dilakukan tiga kali tanam.

Metode budidaya tanaman jagung yang dilakukan petani di wilayah Kota Probolinggo dapat dikatakan seragam, baik dalam hal pengolahan lahan awal berupa pembajakan, pembuatan juringan, pemupukan awal berupa urea, SP-36 dan $\mathrm{KCl}$, serta jarak tanam seragam. Hal ini sudah merupakan kebiasaan dan pengolahan lahan awal, serta pemupukan tidak dilakukan oleh pemilik lahan, akan tetapi dikerjakan secara borongan oleh pihak ketiga berupa tim yang sudah profesional dan memiliki alsintan pendukung. Petani hanya menentukan varietas benih jagung yang akan dibudi dayakan, melakukan perendaman obat anti bulai untuk kemudian diserahkan kepada pihak ketiga tersebut. Untuk selanjutnya petani melakukan penjadwalan pengairan, pemupukan lanjutan dan pemantauan harian kondisi tanaman jagung sejak tanam hingga panen. Seluruh pengeluaran kegiatan budi daya jagung tersaji dalam Tabel 1.

Pengairan tanaman jagung yang dilakukan oleh petani kota Probolinggo adalah dengan sistem pompanisasi air bawah tanah yang difasilitasi oleh kelompok tani. Kelompok tani menyewakan mesin pompa diesel kepada anggota dengan sistem pembayaran harian. Pengairan dengan pompanisasi pada wilayah/daerah yang terdapat air tanah dangkal sangat efektif untuk dikembangkan pada budi daya jagung. Dengan sistem pengairan pompanisasi (sumur dangkal) seperti ini menciptakan sistem sirkulasi air pada lokasi budi daya (Murni \& Arief 2008). Biaya yang harus dikeluarkan oleh petani untuk sekali pengairan adalah Rp. 300.000 /ha/hari.

Penyiangan rumput dilakukan oleh petani secara manual/tanpa obat herbisida. Sama halnya dengan pengolahan lahan awal, kegiatan penyiangan rumput juga dikontrakkan pada pihak ketiga. Dalam hal ini pihak ketiga biasanya merupakan tim yang sudah biasa melayani anggota kelompok tani yang lain. Petani di Probolinggo lebih memilih untuk memberdayakan pihak ketiga dalam penyiangan rumput karena dirasa lebih menghemat 
sumberdaya dan hasilnya lebih bersih dibandingkan dengan dilakukan sendiri. Selain itu penyiangan rumput yang dilakukan oleh petani hanya dilakukan satu kali selama musim tanam, meskipun secara anjuran teknik budi daya adalah dua kali penyiangan. Berdasarkan pengalaman petani, mereka merasakan dampak antara satu kali penyiangan dengan dua kali penyiangan tidak signifikan berpengaruh pada hasil jagung yang dipanen. Hal ini sejalan dengan apa yang disimpulkan Mayadewi (2007) bahwa penggunaan jarak baris antar tanaman jagung sebesar $50 \mathrm{~cm}$ dapat menekan produksi gulma. Jumlah gulma yang tumbuh di sekitar tanaman jagung yang relatif sedikit menjadikan jumlah penyiangan tidak begitu signifikan. Selain itu sistem budi daya monokultur yang dilakukan petani dapat meminimalisir pertumbuhan gulma. Hasil penelitian jagung dengan sistem mono kultur, telah dilakukan oleh Musa et al. (2008), yang menyatakan bahwa pengaturan populasi tanaman melalui pengaturan jarak tanam pada suatu pertanaman sangat penting karena akan mempengaruhi koefisien tanaman dalam memanfaatkan matahari dan persaingan tanaman dalam memanfaatkan hara dan air yang pada akhirnya akan mempengaruhi pertumbuhan dan produksi tanaman.

Usaha tani budi daya tanaman jagung yang dilakukan petani Probolinggo baik sebagai tanaman pakan atau tanaman pangan baru bisa ditentukan pada saat tanaman jagung berumur 70 hari. Hal ini disebabkan karena permintaan tebon jagung segar sebagai pakan sapi potong adalah tebon umur 70 hari, dimana sudah mulai muncul tongkol jagung meskipun masih berupa jagung susu. Pada kondisi ini petani menghitung berdasarkan pengalaman dan prediksi pasar untuk menentukan apakah tanaman jagungnya akan dijual dalam bentuk tebon jagung segar atau dibiarkan untuk mendapatkan panen biji jagung. Untuk penjualan tebon jagung segar petani tidak mengeluarkan biaya pemotongan/ pemanenan. Sistem penjualannya adalah penjualan tebon jagung hidup dengan perhitungan harga persatuan luas. Dengan demikian, biaya pemanenan tebon jagung tidak dimasukkan dalam tabel biaya pengeluaran. Di sisi lain, untuk budi daya jagung sebagai tanaman pangan biaya pemanenan buah jagung, pemipilan jagung hingga pengeringan jagung dimasukkan dalam tabel pengeluaran usaha karena seluruh proses tersebut masih dilakukan sendiri dan membebani petani. Proses pemipilan jagung oleh petani di lokasi penelitian menggunakan mesin pemipil jagung milik kelompok ternak, sedangkan proses pengeringan menggunakan sinar matahari dan dilakukan sendiri oleh petani.

Berdasarkan perhitungan biaya produksi seperti pada Tabel 1, didapatkan bahwa total biaya produksi untuk usaha budi daya tanaman jagung sebagai pakan hingga umur 70 hari adalah sebesar Rp. 9.273.000,00/ha, sedangkan untuk usaha budi daya sebagai tanaman pangan/panen biji jagung adalah sebesar Rp. 12.195.000,00/ha hingga umur 100 hst. Perbedaan biaya produksi antara panen tebon dengan panen jagung hingga mencapai Rp. 2.922.000,00 dipengaruhi oleh pertambahan biaya sewa lahan, pemanenan, pemipilan dan pengeringan jagung. Total biaya ini menunjukkan tingkat modal yang minimal harus disediakan oleh petani dalam rangka usaha budi daya tanaman jagung.

Tujuan utama petani mengelola usahatani adalah untuk mendapatkan penerimaan sebesar-besarnya dengan menekan pengeluaran sehingga petani akan memperoleh pendapatan bersih yang tinggi (Asih 2009). Penerimaan usaha pada penelitian ini hanya antara penjualan tebon jagung segar umur 70 hari dengan penjualan biji jagung pipilan kering. Nilai penjualan tebon jagung untuk umur 80 dan 90 hari tidak dilakukan penghitungan. Hal ini disebabkan karena tidak ada pangsa pasar yang mau menyerap tebon jagung dengan umur diatas 80 hari, mengingat pada umur tersebut tongkol jagung sudah mulai tua dan mengeras. Dari Tabel 2 diketahui bahwa total penerimaan usaha budi daya jagung sebagai tanaman pakan/jual tebon jagung umur 70 hst adalah sebesar Rp. 15.618.556,00. Nilai ini didapatkan dari total produksi biomass tebon jagung segar pada umur 70 hari sebesar 44.624,45 kg dikalikan dengan harga riil pasaran tebon hidup di 
Tabel 1. Pengeluaran usaha budi daya jagung/ha di Kecamatan Kedopok Kota Probolinggo

\begin{tabular}{|c|c|c|c|c|c|c|c|c|c|c|}
\hline \multirow{2}{*}{ Jenis pengeluaran (Rp.) } & \multicolumn{10}{|c|}{ Umur } \\
\hline & $1 \mathrm{hst}$ & 20 hst & 30 hst & $40 \mathrm{hst}$ & 50 hst & 60 hst & 70 hst & 80 hst & 90 hst & $100 \mathrm{hst}$ \\
\hline Sewa lahan milik desa & 17.400 & 348.000 & 522.000 & 696.000 & 870.000 & 1.044 .000 & 1.218 .000 & 1.392 .000 & 1.566 .000 & 1.740 .000 \\
\hline Pengolahan lahan awal & 975.000 & 975.000 & 975.000 & 975.000 & 975.000 & 975.000 & 975.000 & 975.000 & 975.000 & 975.000 \\
\hline Pemupukan dasar & 1.995 .000 & 1.995 .000 & 1.995 .000 & 1.995 .000 & 1.995 .000 & 1.995 .000 & 1.995 .000 & 1.995 .000 & 1.995 .000 & 1.995 .000 \\
\hline Pembelian benih & 1.155 .000 & 1.155 .000 & 1.155 .000 & 1.155 .000 & 1.155 .000 & 1.155 .000 & 1.155 .000 & 1.155 .000 & 1.155 .000 & 1.155 .000 \\
\hline Obat anti-bulai & 210.000 & 210.000 & 210.000 & 210.000 & 210.000 & 210.000 & 210.000 & 210.000 & 210.000 & 210.000 \\
\hline Pemupukan lanjutan & & & 600.000 & 600.000 & 1.200 .000 & 1.200 .000 & 1.200 .000 & 1.200 .000 & 1.200 .000 & 1.200 .000 \\
\hline $\begin{array}{l}\text { Ongkos pemanenan } \\
\text { jagung tua }\end{array}$ & & & & & & & & & & 1.800 .000 \\
\hline $\begin{array}{l}\text { Pemipilan jagung + } \\
\text { pengeringan }\end{array}$ & & & & & & & & & & 600.000 \\
\hline
\end{tabular}


Tabel 2. Penerimaan usaha budi daya jagung di Kecamatan Kedopok, Kota Probolinggo

\begin{tabular}{|c|c|c|c|c|c|c|c|c|c|}
\hline \multirow{2}{*}{ Jenis pendapatan usaha } & \multicolumn{9}{|c|}{ Umur } \\
\hline & $20 \mathrm{HST}$ & $30 \mathrm{HST}$ & $40 \mathrm{HST}$ & 50HST & $60 \mathrm{HST}$ & $70 \mathrm{HST}$ & 80HST & 90HST & 100HST \\
\hline $\begin{array}{l}\text { Produksi biomass tebon jagung } \\
(\mathrm{kg})\end{array}$ & $2.371,25$ & $7.292,74$ & $17.688,00$ & $30.157,25$ & $44.352,00$ & $44.624,45$ & $26.837,18$ & $23.699,81$ & $20.251,97$ \\
\hline Nilai jual tebon jagung $(\mathrm{Rp})$ & 829.936 & 2.552 .457 & 6.190 .800 & 10.555 .03 & 15.523 .200 & 15.618 .556 & & & \\
\hline Produksi jagung pipilan (kg) & & & & & & & & & $6.150,67$ \\
\hline Nilai jual jagung pipilan (Rp) & & & & & & & & & 23.372 .553 \\
\hline $\begin{array}{l}\text { Keuntungan budi daya sebagai } \\
\text { tanaman pakan (Rp) }\end{array}$ & & & & & 6.724 .200 & 6.345 .556 & & & \\
\hline $\begin{array}{l}\text { Keuntungan budi daya sebagai } \\
\text { tanaman pangan }(\mathrm{Rp})\end{array}$ & & & & & & & & & 11.777 .553 \\
\hline $\mathrm{B} / \mathrm{C}$ ratio & & & & & 0,8 & 0,7 & & & 0,9 \\
\hline
\end{tabular}


tegalan pada saat penelitian sebesar Rp. 350/kg. Sistem penjualan di lahan dalam kondisi tanaman hidup memang lazim dilakukan di Probolinggo. Petani yang dalam hal ini bertindak sebagai penjual tidak terbebani biaya apapun. Harga yang ditawarkan para pembeli tebon sudah memperhitungkan biaya potong dan transportasi ke perusahaan penggemukan sapi. Pada kondisi seperti ini keputusan petani untuk segera menjual atau menunda penjualan ditentukan oleh berbagai faktor, antara lain prediksi harga jagung yang akan datang, pengalaman usaha terdahulu dan tingkat kebutuhan yang mendesak. Dengan sistem penjualan tebon umur 70 hari didapatkan keuntungan usaha sebesar Rp. 6.345.556,00 dan nilai $\mathrm{B} / \mathrm{C}$ ratio sebesar 0,7 .

Berdasarkan hasil perhitungan pada Tabel 2, petani budi daya jagung di Probolinggo sebenarnya bisa mendapatkan keuntungan lebih besar pada usaha budi daya jagung sebagai pakan bila dilakukan penjualan pada umur 60 hari yaitu sebesar Rp. 6.724.200,00. Meskipun secara kuantitas berat biomass tebon jagung yang didapatkan pada umur tersebut lebih rendah hanya sebesar $44.352 \mathrm{~kg}$ bila dibandingkan dengan umur 70 hari sebesar $44.624 \mathrm{~kg}$, namun keuntungannya menunjukkan nilai yang lebih tinggi. Hal ini disebabkan oleh biaya sewa tanah pada umur 60 lebih rendah dibandingkan dengan umur 70 hari. Selain keuntungan dalam bentuk rupiah, tingkat keuntungan lain adalah dari segi waktu produksi yang lebih pendek. Namun teknis di lapangan penjualan tebon jagung umur 60 hari ini sulit dilakukan karena permintaan pasar dari perusahaan penggemukan sapi adalah berupa tebon jagung umur 70 hari. Pada umur tersebut kondisi tongkol jagung sudah besar namun belum terlalu keras, sehingga masih dapat di-chop dan diberikan kepada sapi secara langsung sebagai pakan. Dengan demikian, meskipun lebih menguntungkan bagi petani namun tidak ada pembeli yang bersedia untuk melakukan transaksi pembelian di umur 60 hari. Salah satu cara yang dapat dilakukan oleh petani jika menginginkan keuntungan lebih dengan melakukan pemanenan umur 60 hari, adalah dengan melakukan pemanenan sendiri dan melakukan penjualan sendiri secara eceran dalam bentuk ikatan dengan harga Rp. 2.000/ikat dengan berat rataan 4,4 kg. Penggunaan model pemasaran seperti ini lebih menguntungkan petani mengingat harga jual tebon jagung eceran dengan sistem ikatan di tepi jalan adalah Rp. 550/kg. Disisi lain, penjualan secara eceran dalam bentuk ikatan mengandung banyak risiko, yaitu penurunan kualitas pakan dan tidak semua tebon yang dipanen dapat laku terjual.

Produksi biji jagung pada saat panen umur 100 hari adalah sebesar 6.150,67 kg/ha. Bila dibandingkan dengan standar rata-rata produksi jagung BISI 266 yang dikeluarkan oleh Dirjen Tanaman Pangan (2016) yaitu sebesar $10.100 \mathrm{~kg} / \mathrm{ha}$ maka tingkat produksi petani di Probolinggo masih tergolong rendah, yaitu hanya sekitar 60\% dari standar Dirjen Tanaman Pangan. Ini menunjukkan bahwa masih terbuka peluang untuk perbaikan metode budi daya yang dilakukan petani Probolinggo guna meningkatkan produksi.

Penerimaan usaha saat umur panen 100 hari, berupa nilai penjualan biji jagung pipilan kering adalah sebesar Rp. 23.372.553,00. Nilai ini didapatkan dari total produksi biji jagung sebesar 6.150,67 kg dikalikan dengan harga jual biji jagung saat kegiatan evaluasi dilakukan yaitu Rp. 3.800/kg. Dengan sistem usaha budi daya tanaman jagung sebagai tanaman pangan menghasilkan nilai keuntungan usaha sebesar Rp. 11.777.553,00 dan nilai $\mathrm{B} / \mathrm{C}$ ratio sebesar 0,9 . B/C ratio adalah membandingkan present value benefit dengan present value cost (biaya) dan suatu usaha dinyatakan layak serta menguntungkan jika nilainya $>0$ sesuai dengan rumus (Gray et al. 1986). Pada kegiatan evaluasi ini didapatkan bahwa nilai $\mathrm{B} / \mathrm{C}$ ratio untuk kedua jenis usaha tanaman jagung sebagai tanaman pakan maupun sebagai tanaman pangan berturut turut adalah 0,7 dan 0,9. Kedua jenis usaha tersebut dapat dikatakan sama-sama menguntungkan, namun tingkat keuntungan budi daya tanaman jagung sebagai tanaman pangan lebih besar. 
Bila total pengeluaran usaha budidaya jagung dan total pendapatan budi daya jagung baik dalam bentuk tebon jagung segar maupun biji jagung pipilan dihitung secara akumulasi waktu dan kemudian dibuat dalam bentuk grafik, didapatkan profil pengeluaran dan penerimaan seperti pada Gambar 3.

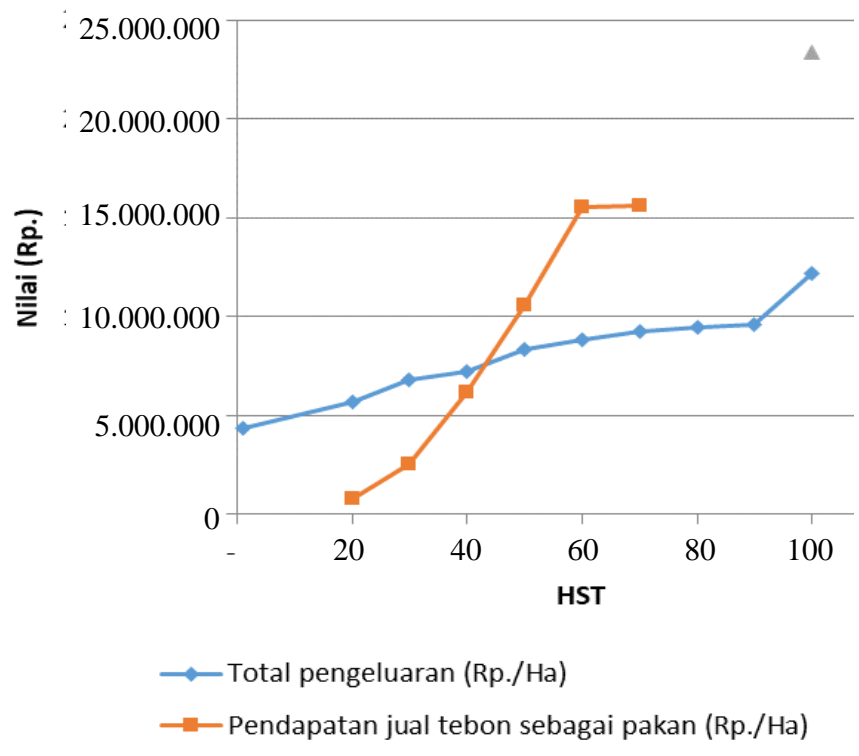

Gambar 3. Grafik pengeluaran dan pendapatan usaha budi daya jagung

Berdasarkan Gambar 3, terlihat bahwa kenaikan nilai pendapatan usaha dari penjualan tebon jagung pada umur 60 dan 70 hari lebih landai daripada kenaikan pengeluaran usaha pada periode yang sama. Hal ini menunjukkan bahwa penjualan tebon jagung pada umur 60 hari lebih menguntungkan secara matematis dibandingkan dengan umur 70 hari. Di sisi lain, perpotongan grafik total pengeluaran dengan total penerimaan terjadi pada periode antara 40 s.d. 50 hari. Hal ini menunjukkan bahwa break even point (BEP) terjadi pada periode tersebut. Analisis BEP merupakan salah satu teknis analisis ekonomi yang berguna dalam hubungan biaya variabel total (TVC) dan biaya tetap total (TFC) terhadap output produksi atau ukuran-ukuran lain dalam aktifitas bisnis dan industri (Gaspersz, 2002). Pada periode umur tanaman jagung berada pada umur 40-50 total penerimaan sama dengan total pengeluaran, sehingga usaha budi daya jagung baru mulai mendapatkan keuntungan setelah umur 50 hari.

\section{KESIMPULAN}

Usaha budi daya jagung sebagai tanaman pangan lebih menguntungkan dengan tingkat keuntungan $\mathrm{Rp}$. 11.777.553,00 dan nilai $\mathrm{B} / \mathrm{C}$ ratio sebesar 0,9 dibandingkan dengan sebagai tanaman pakan dengan keuntungan $\mathrm{Rp}$. 6.345.556,00 dan nilai $\mathrm{B} / \mathrm{C}$ ratio 0,7. Titik BEP usaha budi daya jagung di Kota Probolinggo didapatkan pada umur 40-50 hari.

\section{DAFTAR PUSTAKA}

Asih DN. 2009. Analisis karakteristik dan tingkat pendapatan usahatani bawang merah di Sulawesi Tengah. J Agroland. 16:53-59. 
Dirjen Tanaman Pangan. 2016. Petunjuk teknis pengembangan jagung hibrida [Internet]. [Disitasi 3 Februari 2017]. Tersedia dari: http://tanamanpangan.pertanian.go.id/assets/front/ uploads/document/JUKNIS\%20GERAKAN\%20PENGEMBANGAN\%20JAGUNG\%20HIB RIDA-2016\%20_(final).pdf

Disnak Jatim. 2015. Data statistik populasi ternak kab/kota di Jawa Timur [Internet]. [disitasi 1 Februari 2017]. Tersedia dari: http://disnak.jatimprov.go.id/web/layananpublik/ datastatistik\#

Gazpersz V. 2002. Pedoman penyusunan rencana bisnis. Jakarta (Indonesia): PT Gramedia Pustaka Utama.

Gray C, Simanjuntak P, Sabur LK, Maspaitella PFL. 1986. Pengantar evaluasi proyek. Jakarta (Indonesia): Penerbit Gramedia.

Kasryno F, Pasandaran E, Suyamto, Adnyana O. 2011. Gambaran umum ekonomi jagung di Indonesia. jagung: Teknik produksi dan pengembangan. Bogor (Indonesia): Pusat Penelitian dan pengembangan Tanaman Pangan.

Mayadewi NNA. 2007. Pengaruh jenis pupuk kandang dan jarak tanam terhadap pertumbuhan gulma dan hasil jagung manis. Agritrop. 26:153-159.

Murni AM, Arief RW. 2008. Teknologi budidaya jagung. Bogor (Indonesia): Balai Besar Pengkajian dan Pengembangan Teknologi Pertanian.

Musa Y, Nasruddin, Krurusen MA. 2008. Evaluasi produktivitas jagung melalui pengelolaan populasi tanaman, pengolahan tanah dan dosis pemupukan. J Agrisist. 3:21-33.

Suryandono BN. 2008. Teknik produksi jagung anjuran di lokasi Prima Tani Kabupaten Sumenep. Buletin Teknik Pertanian. 13:27-29.

Tangendjaja B, Wina E. 2007. Limbah tanaman dan produk samping industri jagung untuk pakan. Dalam: Sumarno, Suyamto, Widjono A, Hermanto, Kasim H, penyunting. Jagung: Teknik Produksi dan Pengembangan. Bogor (Indonesia): Pusat Penelitian dan Pengembangan Tanaman Pangan. hlm. 427-455. 